\title{
Anti-Proliferative Activities of Centella Asiatica Extracts on Human Respiratory Epithelial Cells in vitro
}

\author{
Actividades Antiproliferativas del Extracto de Centella Asiatica \\ sobre Células Epiteliales Respiratorias Humanas in vitro
}

P. M. Mutua*; M. M. Gicheru*; A. N. Makanya** \& S. G. Kiama**

MUTUA, P. M.; GICHERU, M. M.; MAKANYA, A. N. \& KIAMA, S. G. Anti-proliferative activities of Centella asiatica extracts on human respiratory epithelial cells in vitro. Int. J. Morphol., 31(4):1322-1327, 2013.

SUMMARY: Centella asiatica or "pegaga" is well known for its ability in promoting wound healing. This study focused on the effect of Centella asiatica on the proliferation of human respiratory epithelial (RE) cells. RE cells were cultured using co-culture techniques until first passage (P1). Viability cell test by tryphan blue dye exclusion assay showed that there was high percentage of cell viability at both P0 (74\%) and P1 (91.61\%). Triplicate MTT assays were carried out with different concentrations of $C$. asiatica from $15.6 \mathrm{ppm}, 31.3$ ppm, 62.5 ppm, 125 ppm, 250 ppm, 500 ppm, 1000 ppm, until 2000 ppm. The higher the concentration of $C$. asiatica, the more inhibitory effect was seen. $C$. asiatica aqueous extract at concentration $1000 \mathrm{ppm}$ and $2000 \mathrm{ppm}$ demonstrated a significant $(\mathrm{p}<0.05)$ inhibitory effect on human RE cells proliferation on day 4 and day 7 after treatment. This provides potential use of $C$. asiatica extract for the treatment of conditions with respiratory epithelial cells overgrowth.

KEY WORDS: Centella asiatica; Respiratory epithelial cells; Anti-proliferative.

\section{INTRODUCTION}

Centella asiatica belongs to the Umbelliferae family. It is also known as Gotu kola in Indian or pennywort in English. It originates from Asia (India, Sri Lanka) and East Africa widespread to South America, West Indies and South East Asia like Malaysia, Pakistan, Japan, China, and Australia. It is commonly found in swampy areas of India, as a weed crop fields and other waste places throughout India up to an altitude of $600 \mathrm{~m}$ (Dastur, 1962). The extract of $C$. asiatica consists of bioactive terpene acids such as Asiatic acids, madecassic acid and their respective glycoside, asiaticoside and madecassoside (Inamdar et al., 1996). C. asiatica has been reported to possess antiulcer (Asakawa et al., 1982; Gohil et al., 2010), antiinflammatory (Guo et al., 2004; George et al., 2009; Huang et al., 2011), immunomodulating (Punturee et al., 2005), antitumor (Babu et al., 1995), antiproliferative (Yoshida et al., 2005), antibacterial (Zaidan et al., 2005), antioxidant (Gupta \& Flora, 2006), and antigenotoxic (Siddique et al., 2007) properties. It is believed that the antioxidation activity of the phenolic compound from $C$. asiatica can prevent certain diseases like arteriosclerosis, cancer, diabetic and arthritis (Zainol et al., 2003). Besides, $C$. asiatica could act as cardio protective agent that can enhance myocardial antioxidants and thus prevents the extent of cardiac damage (Gnanapragasam et al., 2004).

A number of studies have demonstrated the effectiveness of $C$. asiatica triterpenes, in particular the glycoside asiaticoside, in promoting wound healing (Maquart et al., 1999; Shukla et al., 1999a, 1999b). Wound and ulcer healing are enhanced by the promotion of fibroblast proliferation and collagen synthesis in response to topical treatment with extracts of $C$. asiatica herb (Maquart et al., 1990; Maquart et al., 1999). C. asiatica increase the production of bFGF, induce angiogenesis and cell proliferation, therefore it promotes wound healing activity (Shukla et al., 1999a, 1999b; Cheng et al., 2004; Gohil et al.). Asiaticoside enhance the burn wound healing at low doses by promoting angiogenesis during skin wound repair (Kimura et al., 2008).

Besides the above mentioned activities, previous studies reported that $C$. asiatica extract possess antipsoriatic effect due to an inhibition of keratinocyte

\footnotetext{
* Department of Zoological Sciences, Kenyatta University, Nairobi, Kenya.

** Department of Veterinary Anatomy and Physiology, University of Nairobi, Nairobi, Kenya.
} 
proliferation by its constituent triterpenoid glycosides (Sampson et al., 2001). Coldren et al. (2003) found the anti-proliferation effect of $C$. asiatica extract on fibroblast cells. Recent study by Babykutty et al. (2009) shows that C. asiatica extracts induced apoptosis on human breast cancer cells. To date, almost no scientific information is available for the study of effect of $C$. asiatica aqueous extract on human respiratory epithelial cells. Therefore, the present study was designed to study the effect of an aqueous extract of $C$. asiatica on primary human respiratory epithelial cells.

\section{MATERIAL AND METHOD}

Respiratory epithelial tissues isolation and cultivation. The Kenyatta University Research and Ethical Committee approved the usage of redundant human nasal turbinate specimens from consented patient. Human nasal turbinate were obtained from six consented patients undergoing turbinectomy. The tissues were rinsed in phosphate buffer saline (PBS)(Gibco, Grand Island, NY) supplemented with $1 \%$ antibiotic-antimycotic (Invitrogen, Carlsbad, CA) and cut into small pieces $\left(2 \mathrm{~mm}^{3}\right)$ and digested with $0.3 \%$ collagenase type I (Gibco/BRL) for 6-7 hours. After complete digestion, the cell suspension was centrifuged at 5000 rpm for 5 minutes at room temperature. The resulting cell pellet was washed with PBS and centrifuged again to obtain a cell pellet. The cell pellet consisted of respiratory epithelial cells and fibroblasts were then cultured using co-culture technique (Noruddin et al., 2007; Mohd Heikal et al., 2010). in the combination medium of defined keratinocyte serum free medium, Ham's F12 and Dulbecco's Modified Eagle Medium (DKSFM: F12: DMEM; 2:1:1) (Gibco/BRL) + 5\% FBS in six-well plate culture dish. All cultures were maintained at $37^{\circ} \mathrm{C}$ in a humidified 5\% $\mathrm{CO}_{2}$ incubator (Jouan).

When the cells reached $80-90 \%$ confluency, fibroblast were trypsinized with $0.05 \%$ Trypsin-EDTA (Gibco/BRL) leaving the colonies of respiratory epithelial cells in DKSFM only as respiratory epithelial cells culture passage zero ( $\mathrm{P} 0)$. The respiratory epithelial cells were trypsinized again and sub cultured into passage one (P1) once reached $80-90 \%$ confluency.

Determination of cell number and viability. Morphological features of the cells were examined every day using the inverted light microscope (Olympus, Shinjuku-ku, Tokyo) and photomicrographs were recorded. Growth rates (cell/d/ $\left.\mathrm{cm}^{2}\right)$ of cultured respiratory epithelial cells were calculated at every passage.
Preparation of Centella asiatica (CA) aqueous extract. Fresh leaves of $C$. asiatica were identified and voucher specimen no. FRI50032 was deposited at the Medicinal Plant Division, Forest Research Institute of Malaysia (FRIM). The leaves were sun-dried and grounded into a powder. Powdered samples $(250 \mathrm{~g})$ were refluxed with 1.5 liters of distilled water at ratio 1:6 for 3 hours at temperature approximately $40^{\circ} \mathrm{C}$. The extracts were left to cool at room temperature before it was filtered using whatman filter paper. The extract was concentrated on magnetic stirrer until it became half the initial volume. The extract was freeze dried to remove the solvent and the dried extract was stored at $4^{\circ} \mathrm{C}$ until further use.

MTT Assay. MTT assay to measure cell viability and proliferation was used to quantitatively determine the number of viable cells after treatment with $C$. asiatica aqueous extract. Respiratory epithelial cells at P1 were cultured triplicate in 96-well micro titer plate at a density of $1 ¥ 104$ cells/well in DKSFM culture medium for 1-2 days. After the cells reached confluence, medium was changed to F12: DMEM (FD; 1:1) supplemented with indicated amounts of C. asiatica $(15.6 \mathrm{ppm}, 31.3 \mathrm{ppm}, 62.5 \mathrm{ppm}, 125 \mathrm{ppm}, 250$ ppm, $500 \mathrm{ppm}, 1000 \mathrm{ppm}$ and $2000 \mathrm{ppm}$ ). Culture plate was then incubated for 24 hours at $37^{\circ} \mathrm{C}$ in $5 \% \mathrm{CO}_{2}$. MTT solution was added and incubated with the cells for 4 hours. The cells were then lysed to release and solubilize purple formazan. The test was carried out in 3 different days, day1 , day-4 and day-7. The absorbance value of culture in each well was measured at wavelength $570 \mathrm{~nm}$ with background subtraction at $690 \mathrm{~nm}$ by spectrophotometer.

Statistical Analysis. Statistical calculation was done with the SPSS 13.0 software. Data for Respiratory epithelial cells viability and absorbance values were performed as mean \pm standard error of mean (S.E.M.). Statistical differences were determined by Student's t-test and one-way analysis of variance (ANOVA), and the differences among means were considered significant at $\mathrm{p}<0.05$.

\section{RESULTS}

Morphological Analysis and Cell Viability of Human Respiratory Epithelial Cells. Observation under inverted microscope of the co-culture system showed that fibroblast and respiratory epithelial cells have different morphology. Respiratory epithelial cells appeared polygonal while fibroblasts were flat and elongated. The respiratory epithelial cells maintained polygonal morphology from primary culture (P0) to passage one (P1). Both P0 and P1 showed high percentage of cell viability which was $74.2 \%$ (P0) and $91.6 \%$ 
(P1) respectively. The number of respiratory epithelial cells at P1 was slightly higher as compared to the number of cells in P0 (Fig. 1). Statistical analysis through Student's t-test showed that the percentage of cell viability in P1 was significantly higher at $\mathrm{p}<0.05$ when compared to percentage of cell viability in $\mathrm{P} 0$. The results are supported by the findings that respiratory epithelial cells from the nasal turbinates cultured using a co-culture system produced superior quality of respiratory epithelial cells (Noruddin et al.).

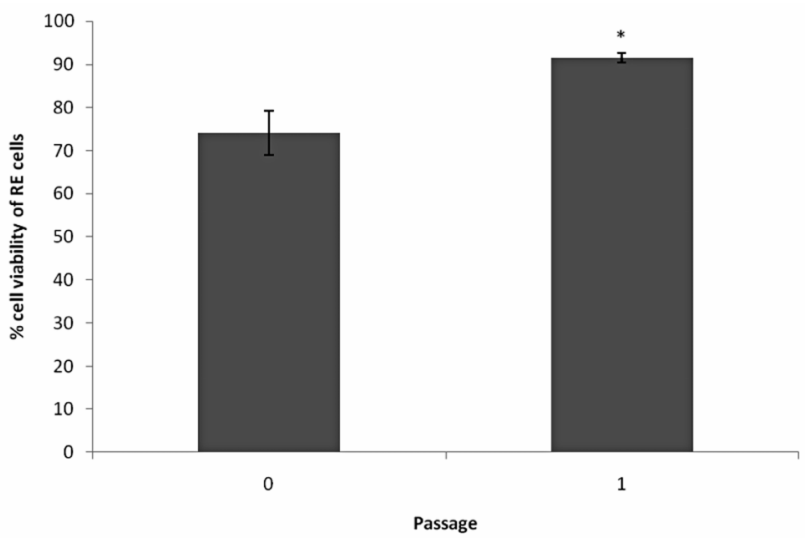

Fig. 1. Percentage of respiratory epithelial cell viability at passage zero $(\mathrm{P} 0)$ and passage one $(\mathrm{P} 1) .{ }^{*} \mathrm{p}<0.05$ showed the significant differences in percentage of cell viability in passage one when compared to the passage zero. The mean values of cell viability for

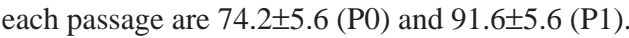

Centella asiatica extract effect on proliferation of respiratory epithelial cells. The proliferation of respiratory epithelial cells culture was evaluated by MTT assay after 1, 4 and 7 days treated with $C$. asiatica aqueous extract. On day-1, C. asiatica aqueous extract at all concentration $(15.6 \mathrm{ppm}$, $31.3 \mathrm{ppm}, 62.5 \mathrm{ppm}, 125 \mathrm{ppm}, 250 \mathrm{ppm}, 500 \mathrm{ppm}, 1000 \mathrm{ppm}$ ) except $2000 \mathrm{ppm}$ demonstrated increases in total number of human nasal respiratory epithelial cells when compared to
DKSFM control but these increments were not significant. On day-4, all culture treated with $C$. asiatica aqueous extract showed an inhibitory pattern towards the respiratory epithelial cells compared to DKSFM control and but only extract at concentration $125 \mu \mathrm{g} / \mathrm{ml}, 1000 \mu \mathrm{g} / \mathrm{ml}$ and $2000 \mu \mathrm{g} / \mathrm{ml}$ showed significant inhibitory effect when compared to the control (Table I). On day-7, culture treated with $C$. asiatica aqueous extract at concentration of $62.5 \mu \mathrm{g} / \mathrm{ml}, 1000 \mu \mathrm{g} / \mathrm{ml}$ and 2000 $\mu \mathrm{g} / \mathrm{ml}$ showed significant inhibitory effect when compared to the DKSFM control (Table I). The numbers of viable cells in culture treated with all concentration on day-7 were lower when compared to day-4. Overall, among the various concentrations of Centella asiatica extract, $2000 \mathrm{ppm}$ and 1000 ppm were found to have anti-proliferative effect on cultured human respiratory epithelial cells. As illustrated in Figure 2, the effect of $C$. asiatica aqueous extract on human respiratory epithelial cells seems to be concentration-dependent where the higher the $C$. asiatica extract concentration, the lower the number of viable human respiratory epithelial cells.

\section{DISCUSSION}

MTT (3-(4,5-dimethylthiazol-2-yl)-2,5-diphenyl tetrazolium bromide) assay applied the principal of formazan crystal formation through dehydrogenase mitochondria activities in living cells. The rate of formation of MTT crystal formazan is directly proportional to the number of living cells. According to Sampson et al., C. asiatica aqueous extract suppressed the proliferation of keratinocytes cell line (SVK14). Coldren et al. found the anti-proliferation effect of $C$. asiatica aqueous extract on human dermal fibroblasts. However, Lu et al. (2004) found C. asiatica aqueous extract induced proliferation of human dermal fibroblast cells. Figure 4 showed that there was inhibitory effect of $C$. asiatica on

Table I. Antiproliferative effect of $C$. asiatica aqueous extract on human respiratory epithelial cells.

\begin{tabular}{|c|c|c|c|c|}
\hline \multirow{2}{*}{$\begin{array}{l}\text { Concentration of } \\
\text { C. asiatica }(\mathrm{ppm})\end{array}$} & \multicolumn{2}{|c|}{ Day-4 } & \multicolumn{2}{|c|}{ Day-7 } \\
\hline & $\begin{array}{c}\text { Absorbance Value } \\
\text { at } 570 \mathrm{~nm}\end{array}$ & $\begin{array}{c}\text { Sig (1-tailed) } \\
\quad * \mathbf{P}<0.05\end{array}$ & $\begin{array}{c}\text { Absorbance Value } \\
\text { at } 570 \mathrm{~nm}\end{array}$ & $\begin{array}{c}\text { Sig (1-tailed) } \\
\quad * * P<0.05\end{array}$ \\
\hline 15.6 & $0.0493 \pm 0.0143$ & 0.079 & $0.0460 \pm 0.0163$ & 0.066 \\
\hline 31.3 & $0.0415 \pm 0.0127$ & 0.065 & $0.0388 \pm 0.0124$ & 0.054 \\
\hline 62.5 & $0.0422 \pm 0.0135$ & 0.056 & $0.0287 \pm 0.0084 * *$ & 0.049 \\
\hline 125 & $0.0447 \pm 0.0142$ & 0.059 & $0.0362 \pm 0.0145$ & 0.051 \\
\hline 250 & $0.0343 \pm 0.009 *$ & 0.045 & $0.0352 \pm 0.0127$ & 0.050 \\
\hline 500 & $0.0363 \pm 0.0125$ & 0.055 & $0.0318 \pm 0.0118$ & 0.052 \\
\hline 1000 & $0.0245 \pm 0.0078 *$ & 0.039 & $0.0157 \pm 0.0045^{*}$ & 0.042 \\
\hline 2000 & $0.0267 \pm 0.0068 *$ & 0.042 & $0.0167 \pm 0.0044 *$ & 0.044 \\
\hline
\end{tabular}

Results are mean \pm SEM of culture treated with C. asiatica after day-4 and day-7. *Significant compared to the DKSFM control at $\mathrm{p}<0.05$. 


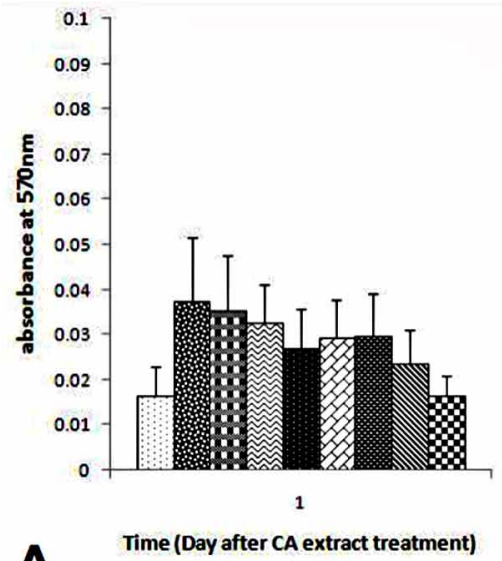

A

Fig. 2. Concentration-dependent effects of $C$. asiatica extract on human Respiratory epithelial cells. Human RE cells were incubated with $C$. asiatica aqueous extracts for the indicated time: day-1(A), day-4(B) and day-7(C). Cell viability was measured by MTT assay. The absorbance value at $570 \mathrm{~nm}$ are expressed as the mean \pm SEM. ${ }^{*} \mathrm{p}<0.05$, **p $<0.05$ and $* * * \mathrm{p}<0.05$ are significant compared with the DK control. DK: Respiratory epithelial cells in DKSFM without C. asiatica treatment.

human RE cells proliferation activities with the decreased in absorbance values at all concentration. According to Sampson et al., the active compounds in C. asiatica extract which are asiaticosside and madecassoside have anti-proliferative effect on keratinocyte cells.

In this study, an inhibitory trend was detected as a response to $C$. asiatica extract. The higher the concentration of $C$. asiatica, the more inhibitory effect was seen. This indicated that the inhibitory effect of $C$. asiatica aqueous extract on respiratory epithelial cells is concentration-dependent.

Observation under inverted microscope showed that nearly all cells contained purple crystal. However, statistical analysis showed no significant mean difference to the formation of crystal formazan when compared to DKSFM control. This might be caused by the condition of cell physiology and variation in dehydrogenase activities in the mitochondria of respiratory epithelial cells. Babykutty et al., had found that $C$. asiatica extracts induced apoptosis on human breast cancer cells by induction of nuclear condensation and loss of mitochondrial membrane potential. This study also showed that the exposure of human respiratory epithelial cell cultures to high concentration of $C$. asiatica aqueous extract (500 ppm - 2000 ppm) may cause cytotoxicity effect on cells.

Studies on the effect of $C$. asiatica on human nasal epithelial cells could help to investigate the potential of this herb for the treatment of nasal polyposis. Nasal polyposis is a chronic inflammatory disease of the mucous membranes in the nose and paranasal sinuses. Increased proliferation of epithelial cells has been well documented in nasal polyp (Coste et al., 1996). The fibroblasts are the main cells of the polyp architecture and play an important role in nasal polyposis (Xing et al., 1993). A number of differentiation factors and inflammatory mediators secreted by fibroblast cells are involved in the growth of nasal polyps (Saji et al., 2000). Activated epithelial cells may be the major source of mediators inducing influx of inflammatory cells that further cause proliferation and activation of fibroblasts leading to nasal polyp formation (Pawliczak et al., 2005). The innate immune mechanism, the growth and homeostasis of epithelial cells, may also play a role in the formation of nasal polyps (Fundová et al., 2008). Since the present study revealed that $C$. asiatica aqueous extract exhibited some inhibitory effect on the proliferation of human respiratory epithelial cells, the identification and characterization of the compounds present in $C$. asiatica extract to determine their particular functions will be part of our future study.

\section{CONCLUSION}

The Centella asiatica aqueous extract demonstrated an inhibitory effect towards the proliferation activities of human respiratory epithelial cells. The effect of inhibition is dose-dependent with, the higher the dose of $C$. asiatica extract the more inhibition will be observed. Further studies are necessary to understand the compounds of Centella asiatica that is responsible for the anti-proliferative effect on human respiratory epithelial cells. This finding provides the possibility of using C. asiatica extract as an anti-polyps therapy.

ACKNOWLEDGEMENT. This study would not be possible without the research grants from Louise Bowditch, Boston, USA. 
MUTUA, P. M.; GICHERU, M. M.; MAKANYA, A. N. \& KIAMA, S. G. Actividades anti-proliferativas del extracto de Centella asiatica sobre células epiteliales respiratorias humanas in vitro. Int. J. Morphol., 31(4):1322-1327, 2013.

RESUMEN: La Centella asiatica o "pegaga" es conocida por su capacidad para promover la cicatrización de heridas. Este estudio se centró en el efecto de la Centella asiatica sobre la proliferación de las células del epitelio respiratorio (ER) humano. Las células del ER se cultivaron usando técnicas de co-cultivo hasta el primer paso (P1). La prueba la viabilidad celular mediante el ensayo de exclusión del colorante azul de tripano demostró un alto porcentaje de viabilidad celular tanto en P0 (74\%) y P1 $(91,61 \%)$. Ensayos de MTT por triplicado se llevaron a cabo con diferentes concentraciones de $C$. asiatica, desde 15,6 ppm, 31,3 ppm, 62,5 ppm, 125 ppm, 250 ppm, 500 ppm, 1000 ppm, hasta 2000 ppm. Con una mayor concentración de $C$. asiatica, se observó un mayor efecto inhibitorio. El extracto acuoso de $C$. asiatica a una concentración de 1000 ppm y 2000 ppm demostró un efecto inhibidor significativo $(\mathrm{p}<0,05)$ sobre la proliferación de células del ER humano los días 4 y 7 posterior al tratamiento. Esto proporciona el uso potencial del extracto de $C$. asiatica para el tratamiento de condiciones con crecimiento excesivo células epiteliales respiratorias.

\section{PALABRAS CLAVE: Centella asiatica; Células epiteliales respiratorias; Antiproliferativos.}

\section{REFERENCES}

Asakawa, Y.; Matsuda, R. \& Takemoto, T. Mono and sesquiterpenoids from hydrocotyle and Centella spesies. Phytochem., 21(10):2590-2, 1982.

Babu, T. D.; Kuttan, G. \& Padikkala, J. Cytotoxic and anti-tumour properties of certain taxa of Umbelliferae with special reference to Centella asiatica (L.) Urban. J. Ethnopharmacol., 48(1):537, 1995.

Babykutty, S.; Padikkala, J.; Sathiadevan, P. P.; Vijayakurup, V.; Azis, T. K.; Srinivas, P. \& Gopala, S. Apoptosis induction of Centella asciatica on human breast cancer cells. Afr. J. Tradit. Complement. Altern. Med., 6(1):9-16, 2008.

Cheng, L. C.; Guo, J. S.; Luk, J. \& Koo, M. W. The healing effects of Centella extract and asiaticoside on acetic acid induced gaastric ulsers in rats. Life Sci., 74(18):2237-49, 2004.

Coldren, C. D.; Hashim, P.; Ali, J. M.; Oh, S. K.; Sinskey, A. J. \& Rha, C. Gene expression changes in the human fibroblast induced by Centella asiatica triterpenoids. Planta Med., 69(8):725-32, 2003.

Coste, A.; Rateau, J. G.; Roudot-Thoraval, F.; Chapelin, C.; Gilain, L.; Poron, F.; Peynegre, R.; Bernaudin, J. F. \& Escudier, E. Increased epithelial cell proliferation in nasal polyps. Arch. Otolaryngol. Head Neck Surg., 122(4):432-6, 1996.

Dastur, J. F. Medicinal Plants of India and Pakistan. Bombay, D. B. Taraporevala Sons and Co., 1962.

Fundová, P.; Filipovsky, T.; Funda, D. P.; Hovorka, O.; Holy, R.; Navara, M. \& Tlaskalova-Hogenova, H. Expression of IGF$1 \mathrm{R}$ and iNOS in nasal polyps; epithelial cell homeostasis and innate immune mechanisms in pathogenesis of nasal polyposis. Folia Microbiol. (Praha), 53(6):558-62, 2008.
George, M.; Joseph, L. \& Ramaswamy. Anti-allergic, anti-pruritic and anti-inflammatory activities of Centella asiatica extracts. Afr. J. Tradit. Complement. Altern. Med., 6(4):554-9, 2009.

Gnanapragasam, A.; Ebenezar, K. K.; Sathish, V.; Govindaraju, P. \& Devaki, T. Protective effect of Centella asiatica on antioxidant tissue defense system against adriamycin induced cardiomyopathy in rats. Life Sci., 76(5):585-97, 2004.

Gohil, K. J.; Patel, J. A. \& Gajjar, A. K. Pharmacological Review on Centella asiatica: A Potential Herbal Cure-all. Indian J. Pharm. Sci., 72(5):546-56, 2010.

Guo, J. S.; Cheng, S. L. \& Koo, M. W. Inhibitory effect of Centella asiatica water extract and asiaticoside on inducible nitric oxide synthase during gastric ulser healing in rats. Planta Med., 70(12):1150-4, 2004.

Gupta, R. \& Flora, S. J. Effect of Centella asiatica on arsenic induced oxidative stress and metal distribution in rats. J. Appl. Toxicol., 26(3):213-22, 2006.

Huang, S. S.; Chiu, C. S.; Chen, H. J.; Hou, W. C.; Sheu, M. J.; Lin, Y. C.; Shie, P. H. \& Huang, G. J. Antinociceptive activities and the mechanisms of anti-inflammation of asiatic Acid in mice. Evid. Based Complement. Alternat. Med., 2011:895857, 2011.

Inamdar, P. K.; Yeole, R. D.; Ghogare, A. B. \& de Souza, N. J. Determination of Biologically Active Constituents in Centella asiatica. J. Chromatogr. A, 742(1-2):127-30, 1996.

Kimura, Y.; Sumiyoshi, M.; Samukawa, K.; Satake, N. \& Sakanaka, M. Facilitating action of asiaticoside at low doses on burn wound repair and its mechanism. Eur. J. Pharmacol., 584(23):415-23, 2008. 
Lu, L.; Ying, K.; Wei, S.; Fang, Y.; Liu, Y.; Lin, H.; Ma, L. \& Mao, Y. Asiaticoside induction for cell-cycle progression, proliferation and collagen synthesis in human dermal fibroblasts. Int. J. Dermatol., 43(11):801-7, 2004.

Maquart, F. X.; Bellon, G.; Gillery, P.; Wegrowski, Y. \& Borel, J. P. Stimulation of collagen synthesis in fibroblast cultures by a triterpene extracted from Centella asiatica. Connect. Tissue Res., 24(2):107-20, 1990.

Maquart, F. X.; Chastang, F.; Simeon, A.; Birembautt, P.; Gillery, P. \& Wigrowski, Y. Triterpenes from Centella asiatica stimulate extracellular matrix accumulation in rat experimental wounds. Eur. J. Dermatol., 9(4):289-96, 1999.

Mohd Heikal, M. Y.; Aminuddin, B. S.; Jeevanan, J.; Chen, H. C.; Sharifah, S. H. \& Ruszymah, B. H. Autologous implantation of bilayered tissue-engineered respiratory epithelium for tracheal mucosal regenesis in a sheep model. Cells Tissues Organs, 192(5):292-302, 2010.

Noruddin, N. A.; Saim, A. B.; Chua, K. H. \& Idrus, R. Human nasal turbinates as a viable source of respiratory epithelial cells using co-culture system versus dispase-dissociation technique. Laryngoscope, 117(12):2139-45, 2007.

Pawliczak, R.; Lewandowska-Polak, A. \& Kowalski, M. L. Pathogenesis of nasal polyps: an update. Curr. Allergy Asthma Rep., 5(6):463-71, 2005.

Punturee, K.; Wild, C. P.; Kasinrerk, W. \& Vinitketkumnuen, U. Immunomodulatory activities of Centella asiatica and Rhinacanthus nasutus extracts. Asian Pac. J. Cancer Prev., 6(3):396-400, 2005.

Saji, F.; Nonaka, M. \& Pawankar, R. Expression of RANTES by IL-1 beta and TNF-alpha stimulated nasal polyp fibroblasts. Auris Nasus Larynx, 27(3):247-52, 2000.

Sampson, J. H.; Raman, A.; Karlsen, G.; Navsaria, H. \& Leigh, I. M. In vitro keratinocyte antiproliferant effect of Centella asiatica extract and triterpenoid saponins. Phytomedicine, 8(3):230-5, 2001.

Shukla, A.; Rasik, A. M. \& Dhawan, B. N. Asiaticoside-induced elevation of antioxidant levels in healing wounds. Phytother. Res., 13(1):50-4, 1999a.

Shukla, A.; Rasik, A. M.; Jain, G. K.; Shankar, R.; Kulshrestha, D. K. \& Dhawan, B. N. In vitro and in vivo wound healing activity of asiaticoside isolated from Centella asiatica. J. Ethnopharmacol., 65(1):1-11, 1999b.

Siddique, Y. H.; Ara, G.; Beg, T.; Faisal, M.; Ahmad, M. \& Afzal, M. Protective role of Centella asiatica L. extract against methylmethane sulphonate and cyclophosphamide induced genotoxic damage in cultured human lymphocytes. Recent Prog. Med. Plants, 19:369-81, 2007.
Xing, Z.; Jordana, M.; Braciak, T.; Ohtoshi, T. \& Gauldie, J. Lipopolysaccharide induces expression of granulocyte/ macrophage colony-stimulating factor, interleukin-8, and interleukin-6 in human nasal, but not lung, fibroblasts: evidence for heterogeneity within the respiratory tract. Am. J. Respir. Cell Mol. Biol., 9(3):255-63, 1993.

Yoshida, M.; Fuchigami, M.; Nagao, T.; Okabe, H.; Matsunaga, K.; Takata, J.; Karube, Y.; Tsuchihashi, R.; Kinjo, J.; Mihashi, K. \& Fujioka, T. Antiproliferative constituents from Umbelliferae plants VII. Active triterpenes and rosmarinic acid from Centella asiatica. Biol. Pharm. Bull., 28(1):173-5, 2005.

Zaidan, M. R.; Noor Rain, A.; Badrul, A. R.; Adlin, A.; Norazah, A. \& Zakiah, I. In vitro screening of five local medicinal plants for antibacterial activity using disc diffusion method. Trop. Biomed., 22(2):165-70, 2005.

Zainol, M. K.; Abd-Hamid, A.; Yusof, S. \& Muse, R. Antioxidative activity and total phenolic compounds of leaf, root and petiole of four accessions of Centella asiatica (L.) urban. Food Chem., 81(4):575-81, 2003.

\section{Correspondence to: \\ Patrick Mutua \\ P.O BOX 339-90137 \\ Kibwezi \\ KENYA}

Email: patmbuvi@gmail.com,

Received: 06-08-2012

Accepted: 06-07-2013 